Check for updates

Cite this: RSC Adv., 2017, 7, 42305

Received 21st July 2017

Accepted 17th August 2017

DOI: $10.1039 / c 7 r a 08054 a$

rsc.li/rsc-advances

\section{Simultaneous removal of phosphorus and dissolved organic matter from a sludge in situ reduction process effluent by coagulants}

\begin{abstract}
Ying An, ${ }^{a}$ Zhen Zhou, (D) *a Weimin Qiao, ${ }^{a}$ Wei Pan ${ }^{b}$ and Zhihui Chen ${ }^{b}$
Owing to the long solids retention time and effective sludge decay, the increase in the amount of phosphorus and dissolved organic matter (DOM) in effluents is a major obstacle to the sludge in situ reduction process. In this study, the coagulants hydrated aluminum sulfate $\left(\mathrm{Al}_{2}\left(\mathrm{SO}_{4}\right)_{3}\right)$, ferric trichloride $\left(\mathrm{FeCl}_{3}\right)$, and polyaluminum chloride (PAC) were applied for the simultaneous removal of phosphorus and DOM from the secondary effluent of a sludge process reduction-activated sludge wastewater treatment system. The results indicated that in most cases, $\mathrm{Al}_{2}\left(\mathrm{SO}_{4}\right)_{3}$ exhibited the best coagulation performance, followed by $\mathrm{FeCl}_{3}$ and PAC. Three-dimensional excitation-emission matrix fluorescence spectroscopy and gel permeation chromatography (GPC) were used for the detailed characterization of the DOM after the coagulation treatment. Herein, two humic-like components and a protein-related component were identified in the wastewater samples by parallel factor (PARAFAC) analysis. The protein-related component was removed more effectively by $\mathrm{FeCl}_{3}$ and $\mathrm{PAC}$, whereas $\mathrm{Al}_{2}\left(\mathrm{SO}_{4}\right)_{3}$ was more effective for the removal of humic-like components. The GPC analysis showed that $\mathrm{FeCl}_{3}$ exhibited the best removal performance for large molecules with a $\mathrm{MW}>1000 \mathrm{kDa}$, whereas $\mathrm{Al}_{2}\left(\mathrm{SO}_{4}\right)_{3}$ showed a relatively good removal performance for small molecules with a $\mathrm{MW}<2 \mathrm{kDa}$. The correlation analysis showed that for the $\mathrm{Al}_{2}\left(\mathrm{SO}_{4}\right)_{3}$ samples, there were significant correlations $(p<0.01)$ between the total organic carbon, UV absorbance at $254 \mathrm{~nm}$, total phosphorus, and maximum fluorescence intensity of the three PARAFAC components; on the other hand, for the $\mathrm{FeCl}_{3}$ and PAC samples, DOM removal was mostly correlated with the humic-like components, and the correlation coefficients among the seven variables were lower than those for the $\mathrm{Al}_{2}\left(\mathrm{SO}_{4}\right)_{3}$ samples.
\end{abstract}

\section{Introduction}

With the dramatic increase in the size and number of wastewater treatment plants (WWTPs), the generation of large amounts of waste-activated sludge (WAS) in the activated sludge process has become a major problem. ${ }^{1}$ Conventional sludge treatment (e.g., thickening, dewatering, and incineration) and disposal (e.g., landfill and land utilization) strategies have become an economic and environmental burden for society because of their complex processes, high operational and transportation costs, land requirements, and strict regulations for the control of hazardous substances. ${ }^{2,3}$ In recent years, many sludge in situ reduction (SIR) approaches have been proposed to decrease the amount of sludge produced in the activated sludge process rather than struggling with its treatment and disposal. ${ }^{4,5}$ In recent years, some SIR processes, such as anaerobic side-stream reactor (ASSR) processes $^{6}$ and the sludge process reduction activated sludge (SPRAS) technology, have

${ }^{a}$ College of Environmental and Chemical Engineering, Shanghai University of Electric Power, Shanghai 200090, China.E-mail: zhouzhen@shiep.edu.cn ${ }^{b}$ Shanghai Municipal Sewerage Co., Ltd., Shanghai 200233, China been successfully applied in full scale WWTPs, and an efficient sludge reduction has been achieved. SIR usually influences pollutant removal in wastewater treatment processes; thus, effective measures should be investigated and employed to guarantee the effluent quality of the SIR process.

During the SIR process, dissolved organic matter (DOM) is released from cell lysis and hydrolysis of particulate organic substances and then utilized by denitrifying biomass to improve nitrogen removal in both $\mathrm{ASSR}^{7,8}$ and the SPRAS system with a micro-aerobic tank and a settler for sludge reduction. ${ }^{9}$ The SIR process decreases the discharged amount of WAS, but it has been reported to hinder the removal of biological phosphorus, ${ }^{8-11}$ whose concentration depends on the amount of phosphorus-accumulating organisms discharged with WAS; furthermore, an increased amount of DOM in the effluents obtained by SIR has been reported, which is attributed to the release of secondary substrates after sludge reduction. ${ }^{7}$ DOM in the effluent is a heterogeneous mixture of various organic substances consisting of non-biodegradable soluble organic matter from influent wastewater and refractory soluble microbial products derived from pollutant degradation and sludge reduction. $^{12,13}$ When subjected to disinfection, DOM is the 
primary source of trihalomethane precursors, ${ }^{\mathbf{1 4}}$ which can cause the effluent to fall below the standards where stringent standards are in place for effluent discharges. For instance, the Grade IV requirement (COD $<30 \mathrm{mg} \mathrm{L}^{-1}$ ) of the Environmental Quality Standards for Surface Water (GB 3838-2002) has been proposed and is ready to be promulgated as a standard for effluent discharges to protect key water resources areas in China. Most of the existing WWTPs fall short of this requirement; ${ }^{15}$ therefore, simultaneous removal of phosphorus and DOM from effluents of the SIR process is necessary.

In this study, phosphorus and DOM in the secondary effluent of an SPRAS system were simultaneously removed by a coagulation treatment. The SPRAS technology was designed for SIR with a sludge process reduction (SPR) modulecomposed of a micro-aerobic tank and a settler, inserted upstream of the conventional AS process. This system performed well for pollutant removal and sludge reduction. ${ }^{9,16,17}$ A detailed characterization of the DOM following the coagulation treatment was carried out by three-dimensional excitation-emission matrix (EEM) fluorescence spectroscopy and gel permeation chromatography (GPC). Parallel factor analysis (PARAFAC) was employed to decompose EEM into individual fluorescent components, which were then correlated with DOM indices to elucidate the DOM removal mechanism by coagulation.

\section{Materials and methods}

\subsection{Water samples and coagulants}

The secondary effluent used in this study was obtained from a pilot-scale SPRAS system $\left(200 \mathrm{~L} \mathrm{~d}^{-1}\right)$ fed with wastewater from the Dongqu WWTP (Shanghai, China). The SPRAS system achieved a sludge reduction efficiency of $68.3 \% .^{9}$ The characteristics of the test effluent were as follows: $\mathrm{pH}=7.22$, total organic carbon $($ TOC $)=9.84 \mathrm{mg} \mathrm{L}^{-1}$, ammonia nitrogen $=0.17 \mathrm{mg} \mathrm{L}^{-1}$, nitrate nitrogen $=11.95 \mathrm{mg} \mathrm{L}^{-1}$, total nitrogen $=16.05 \mathrm{mg} \mathrm{L}^{-1}$, UV absorbance at $254 \mathrm{~nm}\left(\mathrm{UV}_{254}\right)=0.182$, total phosphorus $(\mathrm{TP})$ $=2.87 \mathrm{mg} \mathrm{L}^{-1}$, soluble TP $(\mathrm{STP})=1.78 \mathrm{mg} \mathrm{L}^{-1}$, and orthophosphate phosphorus $(\mathrm{OP})=1.62 \mathrm{mg} \mathrm{L}^{-1}$.

Aluminum sulfate $\left(\mathrm{Al}_{2}\left(\mathrm{SO}_{4}\right)_{3} \cdot 18 \mathrm{H}_{2} \mathrm{O}\right)$, ferric chloride $\left(\mathrm{FeCl}_{3}\right.$ $\cdot 6 \mathrm{H}_{2} \mathrm{O}$ ), and a commercial poly-aluminum chloride (PAC) were used as coagulants for phosphorus removal. $\mathrm{Al}_{2}\left(\mathrm{SO}_{4}\right)_{3}$ and $\mathrm{FeCl}_{3}$ were of analytical grade. The $\mathrm{Al}_{2} \mathrm{O}_{3}$ content of PAC was $11 \%$.

\subsection{Batch tests}

During each experiment, $600 \mathrm{~mL}$ of well-mixed secondary effluent was poured into an $800 \mathrm{~mL}$ glass beaker that was placed in a jar tester (ZR4-6, China). The coagulation process consisted of a fast agitation stage at $280 \mathrm{rpm}$ for $0.5 \mathrm{~min}$, followed by a slow agitation stage at $80 \mathrm{rpm}$ for $15 \mathrm{~min}$, and a $30 \mathrm{~min}$ sedimentation stage. A specified dosage of coagulant was added at the beginning of the fast agitation stage. The zeta potential ( $\zeta$-potential) and $\mathrm{pH}$ values were measured after the fast agitation stage. After the sedimentation stage, the supernatant was taken for TP analysis. Subsequently, the supernatant was filtered through a $0.45 \mu \mathrm{m}$ membrane filter for STP, TOC, $\mathrm{UV}_{254}$, EEM fluorescence, and molecular weight (MW) distribution measurements.

\subsection{Analytical methods}

TP and OP were analyzed following standard methods. ${ }^{18}$ TOC was determined using a multi N/C 3100 analyzer (Analytikjena, Germany). $\mathrm{UV}_{254}$ was measured via a $2802 \mathrm{UV} / \mathrm{vis}$ spectrometer (Unico, USA). The $\mathrm{pH}$ value was measured using an HQ30d portable pH-meter (Hach, USA), and $\zeta$-potentials were determined using a Zetasizer nano Z 90 analyzer (Malvern, UK). The MW distribution of the DOM sample was measured using a GPC analyzer (1206, Agilent, USA). Polyethylene glycols were used as standards for calibration. At various time intervals, the eluate was obtained by an automatic fraction collector and automatically analyzed using a UV spectroscope and a TOC analyzer to obtain a MW distribution.

The EEM fluorescence spectra were obtained using a luminescence spectrometer (RF-5301pc, Shimadzu, Japan). The EEM spectra were obtained using a scanning emission (Em) spectrometer from 220 to $500 \mathrm{~nm}$ at $5 \mathrm{~nm}$ intervals by varying the excitation (Ex) wavelengths from 220 to $500 \mathrm{~nm}$ at $5 \mathrm{~nm}$ sampling intervals. The Ex and Em slits were set at $5 \mathrm{~nm}$ and the scanning speed was set at super. To overcome the overlap problem, spectral data were analyzed using the PARAFAC algorithm to quantitatively determine the components of fluorophores. The PARAFAC analysis was conducted via MATLAB R2013a (Mathworks, MA) using DOMFluor, which contained Nway toolbox version 3.1 (http://www.models.life.ku.dk/).

\section{Results and discussion}

\subsection{Phosphorus and DOM removal by coagulation}

For comparison, chemical dosage was expressed as molar concentration of $\mathrm{Al}^{3+}$ or $\mathrm{Fe}^{3+}$. The influence of $\mathrm{Al}_{2}\left(\mathrm{SO}_{4}\right)_{3}, \mathrm{FeCl}_{3}$, and PAC dosage on phosphorus removal from the secondary effluent is shown in Fig. 1. In the raw secondary effluent, STP was the predominant form $(63.4 \%)$, whereas OP accounted for $89.6 \%$ of STP, which could quickly chemically precipitate with metal ions.

As shown in Fig. 1, the trend for the TP and STP concentrations as a function of dosage with different coagulants was similar. The residual phosphorus in the treated effluent decreased as the dosage increased from 0 to $0.22 \mathrm{mmol} \mathrm{L}^{-1}$. Compared to the residual STP (Fig. 1b), TP in the treated effluent (Fig. 1a) showed higher removal efficiency at a low dosage of $0.01 \mathrm{mmol} \mathrm{L}^{-1}$, attributable to the removal of particulate phosphorus (PP) by coagulation. As shown in Fig. 1a, $\mathrm{Al}_{2}\left(\mathrm{SO}_{4}\right)_{3}$ exhibited the highest phosphorus removal efficiency; TP in the treated effluent decreased to $0.39 \mathrm{mg} \mathrm{L}^{-1}$ at a dosage of $0.13 \mathrm{mmol} \mathrm{L}^{-1}$, which conformed to Grade $1 \mathrm{~A}\left(<0.5 \mathrm{mg} \mathrm{L}^{-1}\right)$ of the state discharge standard GB 18918-2002 of China. The residual TP concentration in the effluent treated with $\mathrm{FeCl}_{3}$ also conformed to Grade 1A of GB 18918-2002 at a dosage of $0.17 \mathrm{mmol} \mathrm{L}^{-1}$. PAC showed the lowest removal efficiency for $\mathrm{TP}$, reaching only $0.61 \mathrm{mg} \mathrm{L}^{-1}$ in the treated effluent, even at a dosage of $0.22 \mathrm{mmol} \mathrm{L}^{-1}$. At the coagulation dosage of $0.22 \mathrm{mmol} \mathrm{L}^{-1}$, the chemical sludge production of PAC $(39.0 \pm$ $\left.1.4 \mathrm{mg} \mathrm{L}^{-1}\right)$ was higher than those of $\mathrm{Al}_{2}\left(\mathrm{SO}_{4}\right)_{3}(16.0 \pm 1.7 \mathrm{mg}$ $\left.\mathrm{L}^{-1}\right)$ and $\mathrm{FeCl}_{3}\left(16.5 \pm 0.7 \mathrm{mg} \mathrm{L}{ }^{-1}\right)$. 

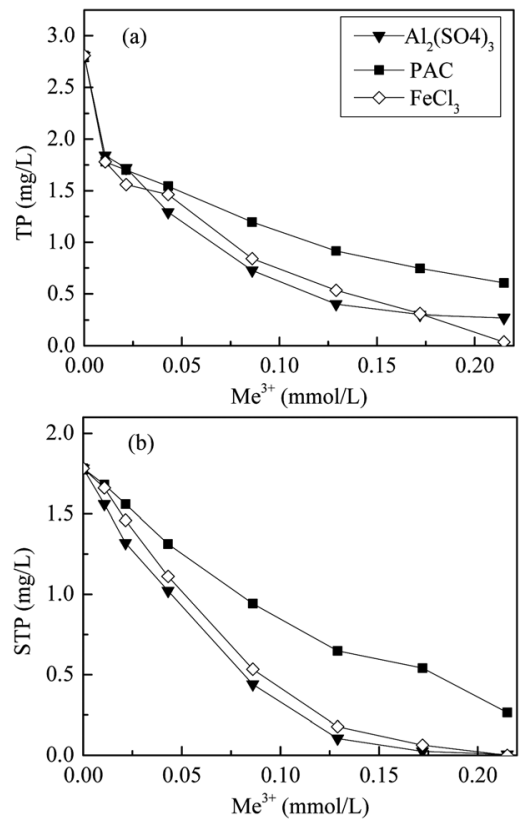

Fig. 1 Effect of dosage on residual TP and STP in the coagulated effluent.

The dissolved organic matter (DOM) in the secondary effluent was partly removed by coagulants, accompanied by phosphorus removal. TOC and $\mathrm{UV}_{254}$ are two commonly used indices for evaluating DOM in wastewater; ${ }^{19}$ TOC represents the level of organic carbon in water and $\mathrm{UV}_{254}$ indicates the amount of aromatic organics, especially humic and fulvic acids. ${ }^{20}$ The results of coagulation on TOC and $\mathrm{UV}_{254}$ are shown in Fig. 2.
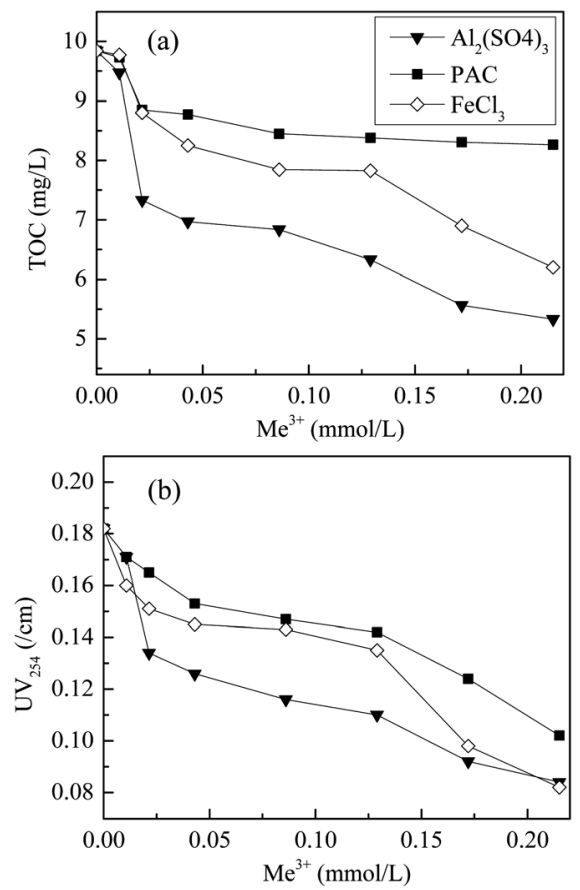

Fig. 2 Effect of dosage on the residual TOC and UV 254 in the coagulated effluent.
The DOM removal efficiency increased sharply at low dosages and then reached a plateau as the coagulant dosage increased. Compared to PAC, the monomeric aluminum salt and iron salt coagulants demonstrated a better performance for DOM removal. At a dosage of $0.22 \mathrm{mmol} \mathrm{L}^{-1}$, the TOC removal efficiency was $45.8 \%, 37.0 \%$, and $16.0 \%$ with $\mathrm{Al}_{2}\left(\mathrm{SO}_{4}\right)_{3}, \mathrm{FeCl}_{3}$, and PAC as coagulants, respectively, whereas the respective efficiency for $\mathrm{UV}_{254}$ was $53.8 \%, 54.9 \%$, and $44.0 \%$, respectively. These results are consistent with previous studies stating that $\mathrm{Al}_{2}\left(\mathrm{SO}_{4}\right)_{3}$ is the most efficient of all coagulants for the treatment of micro-polluted water ${ }^{21,22}$ and wastewater. ${ }^{23} \mathrm{Hu}$ et al. ${ }^{24}$ also reported that the monomeric aluminum salt was more effective than PAC in removing turbidity and DOM in eutrophic water because aluminum ion not only generates $\mathrm{Al}^{3+}$ species, but also functions as a $\mathrm{pH}$ control agent in the coagulation process. Furthermore, investigations on DOM removal from leachate and drinking water also showed that sulfate-based coagulants exhibited a higher removal efficiency than chloride-based coagulants. ${ }^{25}$ These results suggest that the ability of metals to coagulate DOM may be related to the aggregation state of the coagulant and the affinity of the metal for organic matter.

The hydration of the coagulants in water resulted in changes of $\mathrm{pH}$ and colloidal stability and thus affected the aggregation state of the coagulants and their affinity for DOM. ${ }^{26,27}$ The $\mathrm{pH}$ and $\zeta$-potential used to characterize the coagulation performance of the different coagulants are shown in Fig. 3.

As shown in Fig. 3a, pH in the treated effluent decreased as the coagulant dosage increased because the hydration of metal salts is an alkalinity-consuming process. It was noteworthy that the solution $\mathrm{pH}$ dropped to the acidic range after the addition of $\mathrm{Al}_{2}\left(\mathrm{SO}_{4}\right)_{3}$ or $\mathrm{FeCl}_{3}$, whereas only slight $\mathrm{pH}$ changes were observed with PAC. This is due to the fact that inorganic
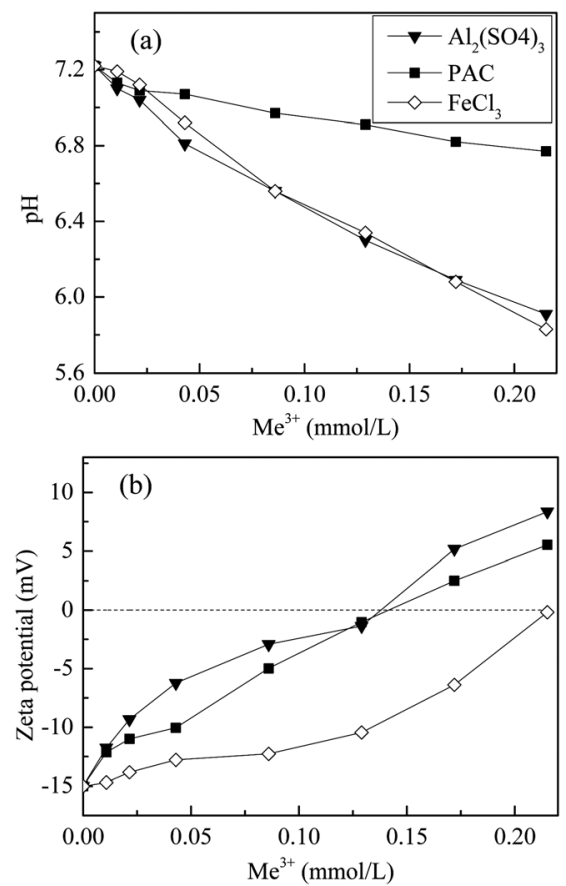

Fig. 3 Changes in the $\mathrm{pH}$ and $\zeta$-potential values for the coagulated effluent as a function of dosage. 
polymeric coagulants such as PAC consume less alkalinity than monomeric metal ions. Overall, acidic conditions favoured coagulation because of the lower negative charge on the particles and the DOM. The improved TP removal with $\mathrm{Al}_{2}\left(\mathrm{SO}_{4}\right)_{3}$ and $\mathrm{FeCl}_{3}$ was also partly attributed to the drop in $\mathrm{pH}$ because the optimal precipitation of metal-phosphate complexes occurs under acidic conditions. ${ }^{28,29}$

Fig. $3 \mathrm{~b}$ shows the changes in the $\zeta$-potential of the flocs formed after rapid stirring with the coagulant. The $\zeta$-potential rapidly increased from negative $(-15.0 \mathrm{mV})$ to positive $(8.4$ and $5.5 \mathrm{mV}$ ) as the $\mathrm{Al}_{2}\left(\mathrm{SO}_{4}\right)_{3}$ and PAC dosage increased, whereas for $\mathrm{FeCl}_{3}$, the $\zeta$-potential never increased above the isoelectric point within the experimental range. The equipotential dosages of $\mathrm{Al}_{2}\left(\mathrm{SO}_{4}\right)_{3}$ and PAC were both about $0.14 \mathrm{mmol} \mathrm{L}^{-1}$. Charge neutralization played a major role during the PAC coagulation process because the $\zeta$-potential was correlated with the PAC dosage (Fig. 3b). ${ }^{30} \mathrm{Al}_{2}\left(\mathrm{SO}_{4}\right)_{3}$ displayed the highest charge neutralization ability at low dosages, resulting in an abrupt decrease of DOM (Fig. 2). The adsorption and enmeshment increased the DOM removal efficiency because of the formation of hydroxide precipitates at higher dosage. ${ }^{24}$ The lower $\zeta$-potential of $\mathrm{FeCl}_{3}$ indicated that adsorption and enmeshment were possibly the dominant mechanisms at the dosages below $0.13 \mathrm{mmol} \mathrm{L}^{-1}$, whereas charge neutralization played a major role at dosages above $0.13 \mathrm{mmol} \mathrm{L}^{-1} \cdot{ }^{\mathbf{3 0 , 3 1}}$ As shown in Fig. 2, TOC and $\mathrm{UV}_{254}$ decreased slowly at dosages below $0.13 \mathrm{mmol} \mathrm{L}^{-1}$ and dropped significantly at higher dosages. Thus, it was concluded that adsorption and enmeshment mechanism of $\mathrm{FeCl}_{3}$ had a lesser effect on the removal of DOM than charge neutralization.

\subsection{Characterization of DOM by coagulation treatment}

3.2.1 EEM fluorescence spectra. Fig. 4 shows the three primary fluorescent components extracted from the EEM dataset by PARAFAC analysis. Component 1 (C1) shows two excitation maxima at 255 and $325 \mathrm{~nm}$ with a single emission maximum at $420 \mathrm{~nm}$. The two peaks in $\mathrm{C} 1$ are short-wavelength humic-like peaks, ascribed to fulvic-like substances. ${ }^{11,32}$ This component is commonly present in water environments and the peak on the left can also be attributed to DOM altered by microbial reprocessing. ${ }^{33}$ Component 2 (C2) displays an excitation maximum at $260 \mathrm{~nm}$ and a secondary excitation peak at $375 \mathrm{~nm}$, with an emission maximum at $460 \mathrm{~nm}$, which has been extensively reported as a humic-like component of terrestrial/ allochthonous origin. ${ }^{32,34,35}$ Component 3 (C3) shows an excitation maximum at $280 \mathrm{~nm}$, with an emission peak at $340 \mathrm{~nm}$, attributed to protein-related structures similar to those of tryptophan or tyrosine..$^{34,36}$

The effect of coagulant addition on DOM fluorescence was evaluated based on the variation in the contribution of the PARAFAC components to the maximum fluorescence intensity $\left(F_{\max }\right)$ in the water samples. $F_{\max }$ is generally used as a surrogate parameter to estimate the relative concentration of PARAFAC components in the DOM pool; $;^{37-39}$ the variation in the contribution of the PARAFAC components to the total $F_{\max }$ was determined to analyze the effect of the coagulation treatment on DOM fluorescence. Fig. 5 shows the $F_{\max }$ levels and contribution of the PARAFAC components to the total $F_{\max }$ of the raw effluent and coagulant-treated effluent, and the removal efficiency of these fluorescence components is also shown. Generally, $F_{\max }$ was highest for the raw effluent and decreased following coagulation. A humic-like component, represented by $\mathrm{C} 1$, was the most abundant fluorophore group in the raw and treated water samples, followed by $\mathrm{C} 3$, representing a protein-related material. The contribution of the humic-like PARAFAC components (C1 and C2) to the total $F_{\max }$ in the raw effluent was $66.6 \%$; this indicated that humic-like material was the major component of
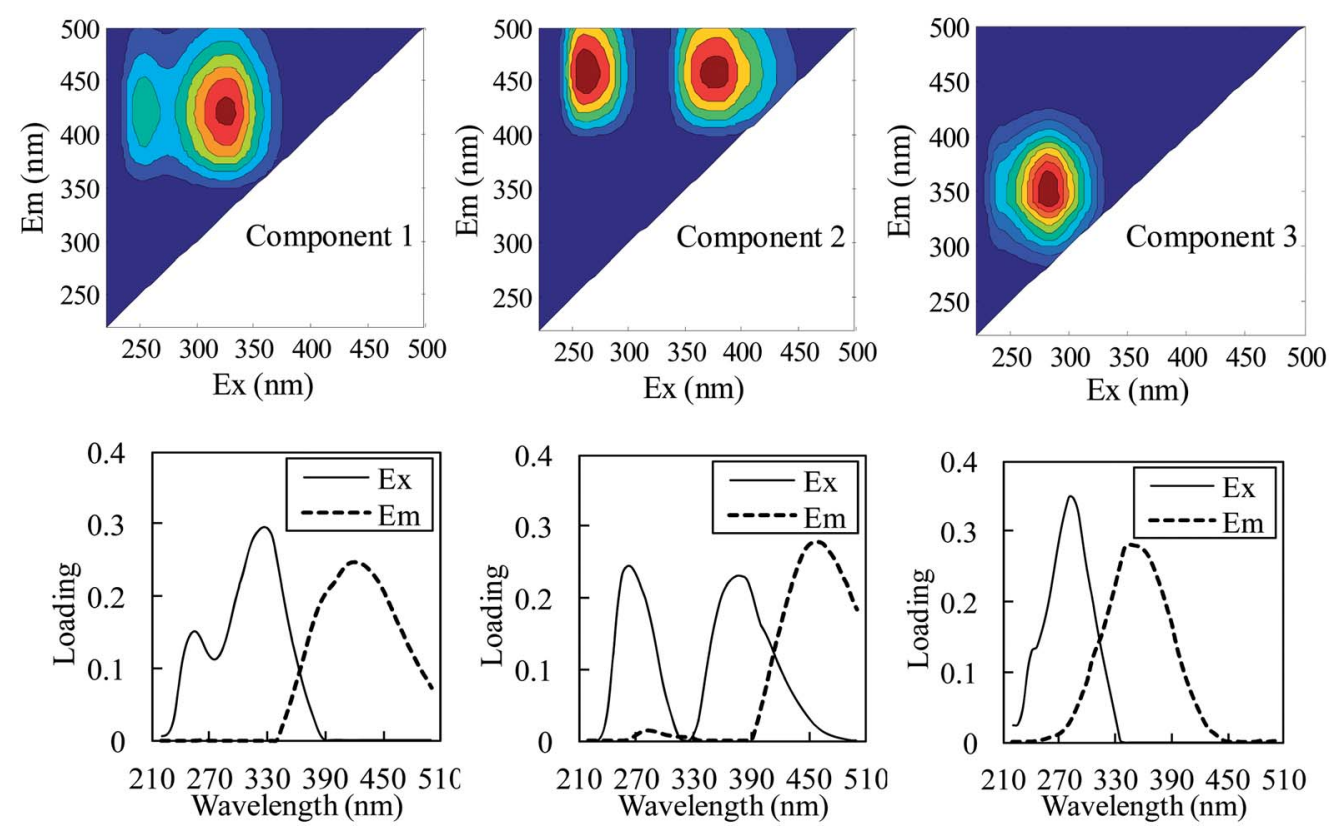

Fig. 4 Fluorescence components and their peak position as determined by PARAFAC. 

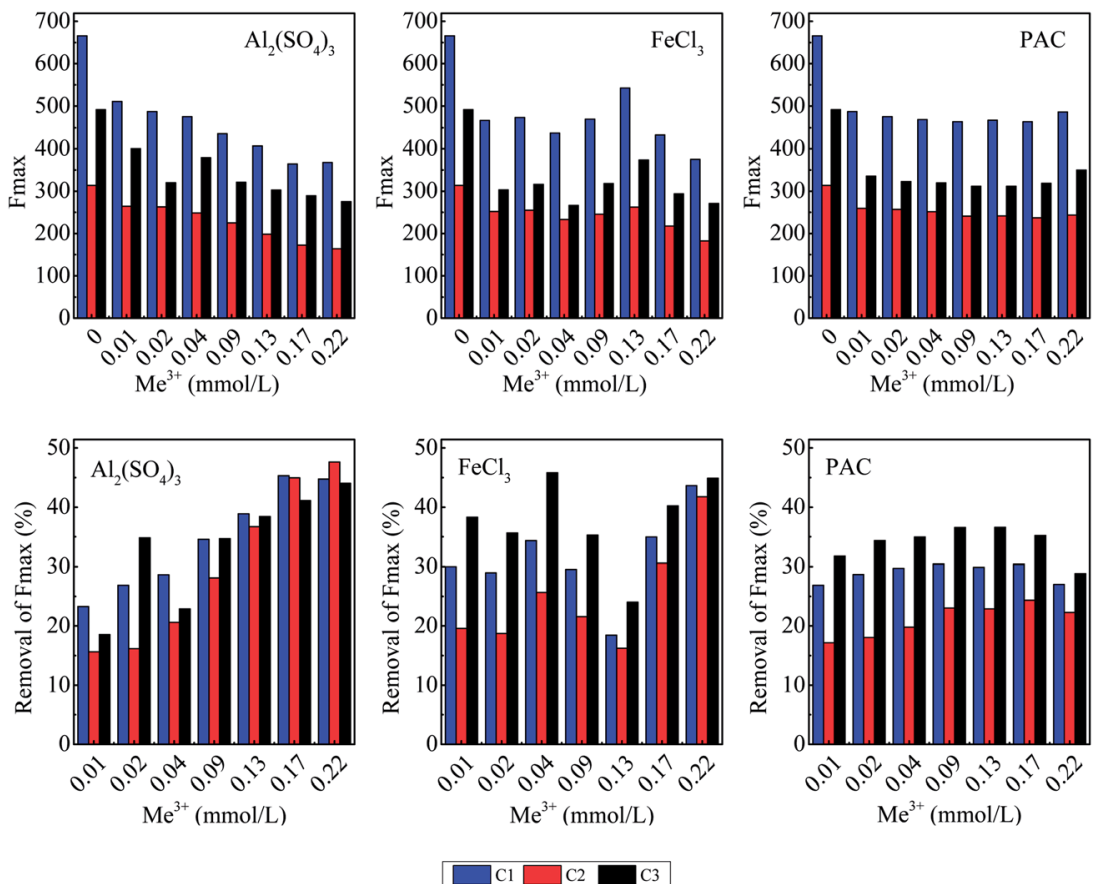

Fig. 5 Removal of the three PARAFAC components at different coagulant dosages

fluorescent DOM. Due to the addition of $\mathrm{FeCl}_{3}$ and PAC, the average percentage of humic-like PARAFAC components in DOM increased to $69.3 \%$ and $69.0 \%$, respectively, whereas the percentage was essentially the same after the addition of $\mathrm{Al}_{2}\left(\mathrm{SO}_{4}\right)_{3}$. These results indicated that $\mathrm{FeCl}_{3}$ and PAC tended to remove the protein-related component, whereas $\mathrm{Al}_{2}\left(\mathrm{SO}_{4}\right)_{3}$ showed similar removal efficiency for both the protein-related and the humic-like components.

It can be seen in Fig. 5 that the responses of each fluorescent component to the range of coagulants and doses were different. The $F_{\text {max }}$ removal percentage of each PARAFAC component increased as the $\mathrm{Al}_{2}\left(\mathrm{SO}_{4}\right)_{3}$ dose increased, with the exception of component $\mathrm{C} 2$ at a dosage of $0.02 \mathrm{mmol} \mathrm{L}^{-1}$; the largest removal rates for $\mathrm{C} 1, \mathrm{C} 2$, and $\mathrm{C} 3$ were $45.3 \%, 47.6 \%$, and $44.0 \%$, respectively. For $\mathrm{FeCl}_{3}$ and $\mathrm{PAC}$, the removal efficiency for the protein-related component was larger than that for the humiclike component. With $\mathrm{FeCl}_{3}$ as the coagulant, each component experienced a relatively high removal efficiency at low dosages as compared to the cases of $\mathrm{Al}_{2}\left(\mathrm{SO}_{4}\right)_{3}$ and PAC. The removal efficiency reached a minimum value when the dosage increased to $0.13 \mathrm{mmol} \mathrm{L}^{-1}$ and then increased as the dosage of $\mathrm{FeCl}_{3}$ increased, achieving a maximum removal rate of $\mathrm{C} 1$ $(43.7 \%)$ and $\mathrm{C} 2(41.8 \%)$ at the highest dosage. As PAC dosage increased, the removal efficiency of each component first increased and then declined, with a maximum a dosage of $0.09 \mathrm{mmol} \mathrm{L}{ }^{-1}$; however, overall, efficiencies (30.4\%, 23.0\%, and $36.6 \%$ for $\mathrm{C} 1, \mathrm{C} 2$, and $\mathrm{C} 3$ ) were less than those for $\mathrm{Al}_{2}\left(\mathrm{SO}_{4}\right)_{3}$ or $\mathrm{FeCl}_{3}$. The difference in the removal efficiencies of the three coagulants may be attributed to the differences in $\mathrm{pH}$ because humic substances tend to aggregate at an acidic $\mathrm{pH}^{\mathbf{4 0}}$

3.2.2 Molecular weight (MW) distribution. To obtain a better understanding of the characteristics of the DOM fraction in different coagulation processes, the MW distributions of the raw and coagulated effluent (treated with $0.22 \mathrm{mmol}$ $\mathrm{L}^{-1} \mathrm{Fe}^{3+}$ or $\mathrm{Al}^{3+}$ ) were analyzed (Fig. 6 and 7). Compared to DOM in the raw effluent, the MW distribution for DOM in the coagulated effluent showed the following changes: (1) the percentage of large molecules ( $\mathrm{MW}>1000 \mathrm{kDa}$ ) decreased the most, i.e. from $17.1 \%$ in the raw effluent to $14.7 \%, 4.1 \%$, and $7.9 \%$ after the addition of $\mathrm{Al}_{2}\left(\mathrm{SO}_{4}\right)_{3}, \mathrm{FeCl}_{3}$, and PAC, respectively; (2) the average percentage reduction of DOM with a MW of $10-50 \mathrm{kDa}$ was $1.7 \%$; (3) the percentage of small molecules (MW $<2 \mathrm{kDa}$ ) decreased $5.4 \%$ and $3.4 \%$ during coagulation with $\mathrm{Al}_{2}\left(\mathrm{SO}_{4}\right)_{3}$ and $\mathrm{PAC}$, respectively, whereas the percentage increased with $\mathrm{FeCl}_{3}$; (4) due to the decrease in the percentage of large molecules, the percentage of DOM with a MW of 2-10 $\mathrm{kDa}$ and 50-200 kDa increased accordingly.

The abovementioned results suggest that larger organic molecules are more easily removed by the coagulation process; this is consistent with observations reported in previous studies. ${ }^{41-43}$ On comparing the removal performance of the three coagulants for molecules with different MWs, it was concluded that $\mathrm{FeCl}_{3}$ exhibited the best removal performance for large molecules with $\mathrm{MW}>1000 \mathrm{kDa}$, whereas $\mathrm{Al}_{2}\left(\mathrm{SO}_{4}\right)_{3}$ performed the worst. By contrast, $\mathrm{Al}_{2}\left(\mathrm{SO}_{4}\right)_{3}$ showed a relatively good removal performance for small molecules with $\mathrm{MW}<2$ $\mathrm{kDa}$. On the other hand, PAC was found to be effective for the removal of both high- and low-MW organics.

\subsection{Correlation analysis of DOM by coagulation treatment}

A correlation analysis was carried out for all samples obtained after coagulation treatment, with the variables TOC concentration, $\mathrm{UV}_{254}$, TP concentration, and $F_{\max }$ for the three PARAFAC components (C1, C2, and $\mathrm{C} 3$; Table 1). For the $\mathrm{Al}_{2}\left(\mathrm{SO}_{4}\right)_{3}$ 


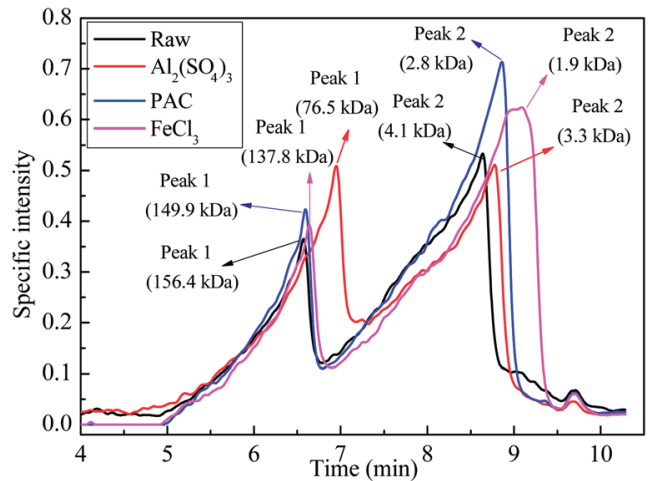

Fig. 6 GPC chromatogram of DOM in the raw and coagulated effluent.

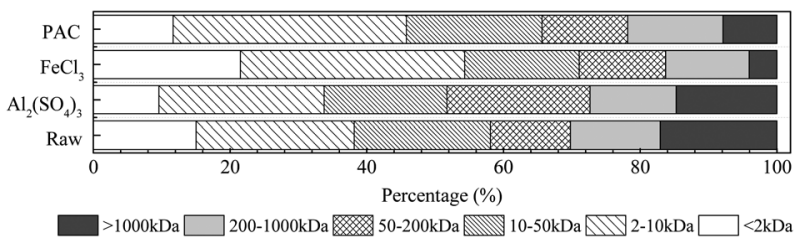

Fig. 7 MW transformation characteristics of DOM in raw and coagulated effluent.

Table 1 Spearman correlation coefficients and significance for each variable in the analysis $(n=8)$

\begin{tabular}{|c|c|c|c|c|c|c|c|}
\hline & & TOC & $\mathrm{UV}_{254}$ & $\mathrm{C} 1$ & $\mathrm{C} 2$ & $\mathrm{C} 3$ & TP \\
\hline \multirow[t]{5}{*}{$\mathrm{Al}_{2}\left(\mathrm{SO}_{4}\right)_{3}$} & TOC & 1 & $1^{a}$ & $0.976^{a}$ & $1^{a}$ & $0.929^{a}$ & $1^{a}$ \\
\hline & $\mathrm{UV}_{254}$ & & 1 & $0.976^{a}$ & $1^{a}$ & $0.929^{a}$ & $1^{a}$ \\
\hline & $\mathrm{C} 1$ & & & 1 & $0.976^{a}$ & $0.905^{a}$ & $0.976^{a}$ \\
\hline & $\mathrm{C} 2$ & & & & 1 & $0.929^{a}$ & $1^{a}$ \\
\hline & C3 & & & & & 1 & $0.929^{a}$ \\
\hline \multirow{5}{*}{$\mathrm{FeCl}_{3}$} & TOC & 1 & $1^{a}$ & 0.643 & $0.714^{b}$ & 0.429 & $1^{a}$ \\
\hline & $\mathrm{UV}_{254}$ & & 1 & 0.643 & $0.714^{b}$ & 0.429 & $1^{a}$ \\
\hline & $\mathrm{C} 1$ & & & 1 & $0.976^{a}$ & $0.905^{a}$ & 0.643 \\
\hline & $\mathrm{C} 2$ & & & & 1 & $0.857^{a}$ & $0.714^{b}$ \\
\hline & C3 & & & & & 1 & 0.429 \\
\hline \multirow[t]{5}{*}{ PAC } & TOC & 1 & $1^{a}$ & 0.571 & $0.833^{b}$ & 0.429 & $1^{a}$ \\
\hline & $\mathrm{UV}_{254}$ & & 1 & 0.571 & $0.833^{b}$ & 0.429 & $1^{a}$ \\
\hline & $\mathrm{C} 1$ & & & 1 & $0.905^{a}$ & $0.905^{a}$ & 0.571 \\
\hline & $\mathrm{C} 2$ & & & & 1 & $0.762^{b}$ & $0.833^{b}$ \\
\hline & C3 & & & & & 1 & 0.429 \\
\hline
\end{tabular}

${ }^{a}$ Correlation is significant at the 0.01 level (two-tailed). ${ }^{b}$ Correlation is significant at the 0.05 level (two-tailed).

samples, there were significant correlations $(p<0.01)$ between TOC concentration, $\mathrm{UV}_{254}$, TP concentration, and $F_{\max }$ for the three PARAFAC components. The correlation between TOC concentration, $\mathrm{UV}_{254}$, and TP concentration was stronger with $\mathrm{C} 2$ than with $\mathrm{C} 1$ or with $\mathrm{C} 3$. The results were in agreement with those obtained by Gone et al. for the coagulation of tropical surface water with $\mathrm{Al}_{2}\left(\mathrm{SO}_{4}\right)_{3}$, indicating that $\mathrm{Al}_{2}\left(\mathrm{SO}_{4}\right)_{3}$ coagulation had insignificant selectivity for fluorescent substances in DOM. ${ }^{44}$ However, for $\mathrm{FeCl}_{3}$ and PAC samples, the relationship between three PARAFAC components, TOC concentration,
$\mathrm{UV}_{254}$, and TP concentration was weaker than that for the $\mathrm{Al}_{2}\left(\mathrm{SO}_{4}\right)_{3}$ samples. The relationship between $\mathrm{C} 2$ and TOC concentration (as well as $\mathrm{UV}_{254}$ and TP concentration) had the lowest correlation coefficient for the $\mathrm{FeCl}_{3}$ samples as compared to the case of other two coagulants. Contrary to $\mathrm{C} 2$, there was no significant correlation observed between C1 (as well as C3) and TOC concentration, $\mathrm{UV}_{254}$, and TP concentration. This was because $F_{\max }$ values of $\mathrm{C} 1$ and $\mathrm{C} 3$ were both insensitive to the dosage of $\mathrm{FeCl}_{3}$ and PAC (Fig. 5). Interestingly, TOC concentration, $\mathrm{UV}_{254}$, and $\mathrm{TP}$ concentration consistently had strong correlations with each other for these three coagulants.

\section{Conclusions}

The simultaneous removal of phosphorus and DOM from the effluent of a SPRAS process for SIR was investigated by coagulation treatment with three different coagulants $\left(\mathrm{Al}_{2}\left(\mathrm{SO}_{4}\right)_{3}\right.$, $\mathrm{FeCl}_{3}$, and PAC). In most cases, $\mathrm{Al}_{2}\left(\mathrm{SO}_{4}\right)_{3}$ exhibited the best coagulation performance, followed by $\mathrm{FeCl}_{3}$ and PAC. PARAFAC analysis of three-dimensional EEM fluorescence spectra showed that the protein-related component were more effectively removed by $\mathrm{FeCl}_{3}$ and $\mathrm{PAC}$, whereas $\mathrm{Al}_{2}\left(\mathrm{SO}_{4}\right)_{3}$ was more effective for removing the humic-like components. $\mathrm{FeCl}_{3}$ exhibited the best removal performance for large molecules, with $\mathrm{MW}>$ $1000 \mathrm{kDa}$, whereas $\mathrm{Al}_{2}\left(\mathrm{SO}_{4}\right)_{3}$ showed a relatively good removal performance for smaller molecules, with $\mathrm{MW}<2 \mathrm{kDa}$. PAC was found to be effective for the removal of both high- and low-MW organics. The correlation analysis showed that for the $\mathrm{Al}_{2}\left(\mathrm{SO}_{4}\right)_{3}$ samples, there were significant correlations $(p<0.01)$ between TOC, $\mathrm{UV}_{254}$, TP, and $F_{\max }$ of the three PARAFAC components. On the other hand, for the $\mathrm{FeCl}_{3}$ and PAC samples, DOM removal was primarily correlated with the humic-like component, and the correlation coefficients among the seven variables were lower than those for the $\mathrm{Al}_{2}\left(\mathrm{SO}_{4}\right)_{3}$ samples.

\section{Conflicts of interest}

We declare that we do not have any commercial or associative interest that represents a conflict of interest in connection with the work submitted.

\section{Acknowledgements}

We thank the Shanghai Rising-Star Program (16QA1401900), the National Natural Science Foundation of China (51408352), and the Chinese National 863 Program (2012AA063403) for providing financial support for this study.

\section{References}

1 A. Khursheed and A. A. Kazmi, Water Res., 2011, 45, 4287.

2 M. T. Nguyen, N. H. Mohd Yasin, T. Miyazaki and T. Maeda, Chemosphere, 2014, 117, 552.

3 T. H. Niu, Z. Zhou, W. C. Ren, L. M. Jiang, B. Y. Li, H. J. Wei, J. Li and L. C. Wang, Int. Biodeterior. Biodegrad., 2016, 106, 170. 
4 P. Yan, J. S. Guo, J. Wang, Y. P. Chen, F. Y. Ji, Y. Dong, H. Zhang and W. J. Ouyang, Bioresour. Technol., 2015, 183, 181.

5 D. H. Nam and K. H. Kang, Water Sci. Technol., 2013, 67, 2838.

6 V. F. Velho, P. Foladori, G. Andreottola and R. H. R. Costa, J. Environ. Manage., 2016, 177, 223.

7 C. Cheng, Z. Zhou, T. H. Niu, Y. An, X. Y. Shen, W. Pan, Z. H. Chen and J. Liu, Bioresour. Technol., 2017, 234, 380.

8 Z. Zhou, W. M. Qiao, C. Xing, Y. An, X. L. Shen, W. C. Ren, L. M. Jiang and L. C. Wang, Chem. Eng. J., 2015, 266, 249.

9 T. H. Niu, Z. Zhou, X. L. Shen, W. M. Qiao, L. M. Jiang, W. Pan and J. J. Zhou, Water Res., 2016, 90, 369.

10 W. Q. Guo, S. S. Yang, W. S. Xiang, X. J. Wang and N. Q. Ren, Biotechnol. Adv., 2013, 31, 1386.

11 W. T. Li, S. Y. Chen, Z. X. Xu, Y. Li, C. D. Shuang and A. M. Li, Environ. Sci. Technol., 2014, 48, 2603.

12 P. K. Jin, X. Jin, X. C. C. Wang and X. B. Shi, Chemosphere, 2013, 91, 558.

13 Z. Zhou, W. M. Qiao, C. Xing, C. Y. Wang, L. M. Jiang, Y. T. Gu and L. C. Wang, Chem. Eng. J., 2015, 259, 357.

14 D. F. Ma, B. Y. Gao, S. L. Sun, Y. Wang, Q. Y. Yue and Q. Li, Bioresour. Technol., 2013, 136, 535.

15 Q. H. Zhang, W. N. Yang, H. H. Ngo, W. S. Guo, P. K. Jin, M. Dzakpasu, S. J. Yang, Q. Wang, X. C. Wang and D. Ao, Environ. Int., 2016, 92, 11.

16 Z. Zhou, W. M. Qiao, C. Xing, X. L. Shen, D. L. Hu and L. C. Wang, Bioresour. Technol., 2014, 173, 452.

17 Z. Zhou, W. M. Qiao, C. Xing, Y. J. Wang, C. Y. Wang, Y. F. Wang, Y. R. Wang and L. C. Wang, Water Sci. Technol., 2014, 69, 934.

18 Chinese NEPA, Water and Wastewater Monitoring Methods, Chinese Environmental Science Publishing House, Beijing, China, 4th edn, 2012.

19 W. P. Cheng, F. H. Chi and R. F. Yu, Environ. Monit. Assess., 2004, 98, 421.

20 C. Musikavong and S. Wattanachira, Environ. Monit. Assess., 2007, 134, 489.

21 H. Selcuk, L. Rizzo, A. N. Nikolaou, S. Meric, V. Belgiorno and M. Bekbolet, Desalination, 2007, 210, 31.

22 M. Yan, D. Wang, J. Qu, J. Ni and C. W. Chow, Water Res., 2008, 42, 2278.

23 T. Park, V. Ampunan, S. Lee and E. Chung, Chemosphere, 2016, 144, 2264.
24 C. Z. Hu, H. J. Liu, J. H. Qu, D. S. Wang and J. Ru, Environ. Sci. Technol., 2006, 40, 325.

25 S. E. Comstock, T. H. Boyer, K. C. Graf and T. G. Townsend, Chemosphere, 2010, 81, 976.

26 E. Tipping, C. Rey-Castro, S. E. Bryan and J. Hamilton-Taylor, Geochim. Cosmochim. Acta, 2002, 66, 3211.

27 H. Kerndorff and M. Schnitzer, Geochim. Cosmochim. Acta, 1980, 44, 1701.

28 J. Matusik, T. Bajda and M. Manecki, J. Hazard. Mater., 2008, 152, 1332.

29 Z. Djedidi, J. Ben Khaled, R. Ben Cheikh, J. F. Blais, G. Mercier and R. D. Tyagi, Hydrometallurgy, 2009, 95, 61.

30 Y. X. Zhao, B. Y. Gao, Q. B. Qi, Y. Wang, S. Phuntsho, J. H. Kim, Q. Y. Yue, Q. Li and H. K. Shon, J. Hazard. Mater., 2013, 258, 84.

31 Z. L. Yang, B. Y. Gao and Q. Y. Yue, Chem. Eng. J., 2010, 165, 122.

32 S. A. Baghoth, S. K. Sharma and G. L. Amy, Water Res., 2011, 45, 797.

33 D. Suor, J. X. Ma, Z. Y. Wang, Y. L. Li, J. X. Tang and Z. C. Wu, Chem. Eng. J., 2014, 248, 415.

34 P. Kowalczuk, W. J. Cooper, M. J. Durako, A. E. Kahn, M. Gonsior and H. Young, Mar. Chem., 2010, 118, 22.

35 N. P. Sanchez, A. T. Skeriotis and C. M. Miller, Water Res., 2013, 47, 1679.

36 K. R. Murphy, C. A. Stedmon, T. D. Waite and G. M. Ruiz, Mar. Chem., 2008, 108, 40.

37 N. P. Sanchez, A. T. Skeriotis and C. M. Miller, Environ. Sci. Technol., 2014, 48, 1582.

38 M. Ruscalleda, B. Seredynska-Sobecka, B. J. Ni, E. Arvin, M. D. Balaguer, J. Colprim and B. F. Smets, Chemosphere, 2014, 117, 271.

39 G. P. Sheng and H. Q. Yu, Water Res., 2006, 40, 1233.

40 Z. Zhou, D. L. Hu, W. C. Ren, Y. Z. Zhao, L. M. Jiang and L. C. Wang, Chemosphere, 2015, 141, 94.

41 E. C. Wert, S. Gonzales, M. M. Dong and F. L. Rosario-Ortiz, Water Res., 2011, 45, 5191.

42 J. Haberkamp, A. S. Ruhl, M. Ernst and M. Jekel, Water Res., 2007, 41, 3794.

43 B. P. Allpike, A. Heitz, C. A. Joll, R. I. Kagi, G. Abbt-Braun, F. H. Frimmel, T. Brinkmann, N. Her and G. Amy, Environ. Sci. Technol., 2005, 39, 2334.

44 D. L. Gone, J. L. Seidel, C. Batiot, K. Bamory, R. Ligban and J. Biemi, J. Hazard. Mater., 2009, 172, 693. 